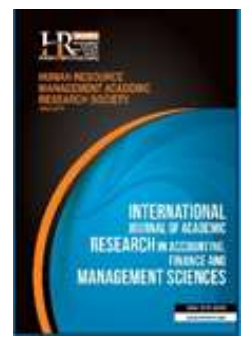

International Journal of Academic Research in Accounting, Finance and Management Sciences

Vol. 9, No.4, October 2019, pp. 36-42

E-ISSN: 2225-8329, P-ISSN: 2308-0337

(C) 2019 HRMARS

www.hrmars.com

To cite this article: lacob, S.V., Petre (Olteanu), A., Olteanu, C., Stoica, R. (2019). Construction and Structure of the

Basic Model Used in Macroeconomic Analysis, International Journal of Academic Research in Accounting, Finance

and Management Sciences 9 (4): $36-42$

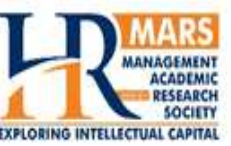

http://dx.doi.org/10.6007/IJARAFMS/v9-i4/6631 (DOI: 10.6007/IJARAFMS/v9-i4/6631)

\title{
Construction and Structure of the Basic Model Used in Macroeconomic
} Analysis

\author{
Ștefan Virgil lacob ${ }^{1}$, Alexandra Petre (Olteanu) ${ }^{2}$, Cristian Olteanu $^{3}$, Radu Stoica ${ }^{4}$ \\ ${ }_{1}^{1}$,Artifex" University of Bucharest, Romania, ${ }^{1}$ E-mail: stefaniacob79@yahoo.com \\ 2,3,4 Bucharest University of Economic Studies, Romania, \\ 2,3E-mail: alexandra.olteanu.s1@anaf.ro, ${ }^{4}$ E-mail: radustoica68@yahoo.com
}

\begin{abstract}
In the study of macroeconomic models, we mainly start from a basic model, which explains the correlations that are established between the economic variables and the proportions that must exist between them, so that a balanced evolution can be achieved, which has the effect of at the macroeconomic level. The balance is not maintained automatically and therefore some measures must be taken to ensure the return of production to an appropriate level characterized by stability. Normally, unemployment is a balancing element in the sense that, when production is realized above market demands, a restructuring of the workforce is needed. This can be done through professional conversion or through unemployment. The issue regarding what is more advantageous, the production of unsold stocks at the level of the national economy or in a certain field, or the cessation of its production, with the effect of passing a number of employees into unemployment, must be addressed. Also, another element that causes distortions in maintaining the balance, which we find in the basic model, is that of inflation. Inflation, as opposed to deflation, is a factor that influences consumption and at the same time influences investment. Consumption is influenced in the sense that if inflation is very high, prices increase and then consumption is reduced. But all inflation causes a part of the monetary mass to be released and thus to return to the equilibrium element. Liquidity must be correlated with inflation and the mechanism of inflation.

Key words Equilibrium, Consumption, Inflation, Deflation, Market, Model

\begin{tabular}{|c|c|c|}
\hline Received: & 10 Nov 2019 & (C) The Authors 2019 \\
\hline Revised: & 18 Nov 2019 & Published by Human Resource Management Academic Research Society (www.hrmars.com) \\
\hline $\begin{array}{l}\text { Accepted: } \\
\text { ed Online: }\end{array}$ & $\begin{array}{l}02 \text { Dec } 2019 \\
06 \text { Dec } 2019\end{array}$ & $\begin{array}{l}\text { This article is published under the Creative Commons Attribution (CC BY } 4.0 \text { ) license. Anyone may } \\
\text { reproduce, distribute, translate and create derivative works of this article (for both commercial and } \\
\text { non-commercial purposes), subject to full attribution to the original publication and authors. The full } \\
\text { terms of this license may be seen at: http://creativecommons.org/licences/by/4.0/legalcode }\end{array}$ \\
\hline
\end{tabular}
\end{abstract}

\section{Introduction}

In the article the basic model - uses at the macroeconomic level, the authors sought to explain and substantiate some aspects regarding the application of the basic model that takes into account all the factorial aspects that can have an effect on the evolution of the production. Thus, a comparative study is made regarding the unemployment and the level that can ensure a balance, the way to access the use of the entire labor force resource, but also the consequences that can be resorted to from this if more occurs than the market demands.

Here we must implement a new variable, namely the correlation between the market (domestic production) and the international market. As long as national production is decisive in determining consumption and investments, we must find that at international level we can place surpluses of products only in conditions of quality and price to be accepted by the international market. The study is then 
deepened on the effects of inflation and deflation, as well as on the effect that the monetary mass has, to which we generically tell the liquidities that can cause an influence in one direction or another.

The authors then approached inflation in the context of the basic model, with an emphasis on the mechanism of inflation, the effect of liquidity on inflation to reach the possibility of realistically, correctly, constructing this basic model, which would satisfy the prospect of an evolution, which would tend towards an economic balance, which does not impose harmful developments on macroeconomic results.

\section{Literature review}

Anghelache et al. (2019a) analyzes some econometric concepts and models for analyzing macroeconomic performance. Anghelache et al. (2019b) analyzes the main indicators of national wealth that have an effect on macroeconomic performance. Anghelache and Anghel (2019), addresses in their work theoretical and practical aspects regarding economic statistics. Anghelache and Anghel (2019), it addresses the problems of economic modeling. Anghelache et al. (2019c) analyzes models used in dynamic series analysis. Bollerslev and Wooldridge (1992) are concerned with estimating the probabilities and interference of dynamic models that are time-varying. Ledoit and Wolf (2003) are concerned about estimating stock returns with a portfolio selection request. Ruth and Hannan (2012) they turn their attention to their analysis of dynamic economic systems. In this article addresses problems related to nonparametric estimation and analyzes the degree of sensitivity of the predicted deficiency (Scaillet, 2004). Stambaugh and Yuan (2017) raise the issue of factors not taken into account that influence the various economic phenomena.

\section{Methodology, data, discussions, results}

We consider that the most important application of the basic model is to provide at least an explanation of the phenomenon of economic depression and unemployment. There is no clarity in the balance of the model as we described, which says that the equilibrium position of the output is at the output power. Therefore, the balance may be at a level lower than the level at which the company is able to be in balance, even with the limited resources available to it. If the equilibrium output is given by:

$$
\begin{aligned}
& C=C_{o}+a_{c} P \\
& I=A_{o}+a_{i} P
\end{aligned}
$$

Then in equilibrium $\mathrm{I}=\mathrm{A}$ and $\mathrm{P}=\mathrm{C}+\mathrm{A}$, from which we deduce the relations:

$$
\begin{aligned}
& C+A=C_{o}+A_{o}+\left(a_{c}+a_{i}\right) P=P \\
& P=\frac{C o+A o}{1-\left(a_{c}+a_{i}\right)}
\end{aligned}
$$

Where: $C_{o}$ and $A_{o}$, are parameters that measure the size of the anticipated consumption or accumulation.

We find that the accumulation and consumption are higher and the higher they will be, the inclinations to consume and invest, from a value of equilibrium of $P$, and it is quite high. A measure of unemployment is the difference between production capacity and actual or equilibrium production.

Following figure 1 , we find that $\mathrm{OO}_{\mathrm{t}}$ represents the output power. The equilibrium output is $\mathrm{OO}_{\mathrm{e}}$. The difference, $\mathrm{O}_{e} \mathrm{O}_{t}$ is that production that could be produced but not produced because there are no resources.

\section{- Unemployment equilibrium}

If we now ask why there is unemployment, the answer is found in a study of what would happen if the system actually worked at capacity, ie at $\mathrm{OO}_{\mathrm{f}}$. At this level of production we see that consumption and investments are insufficient to absorb the entire product. In other words, there is a shortage of effective demand. This is itself reflected in the additional accumulations amounting to $\mathrm{B}_{\mathrm{f}} \mathrm{K}_{\mathrm{f}}=\mathrm{O}_{\mathrm{f}} \mathrm{S}_{\mathrm{f}}$. These accumulations cause a downward pressure on production, so the economy is in decline. At full employment, it will accumulate stocks of unsolicited market goods. As a result of this situation, 
unemployment becomes a solution to reduce the rate of production that cannot be absorbed by the market.

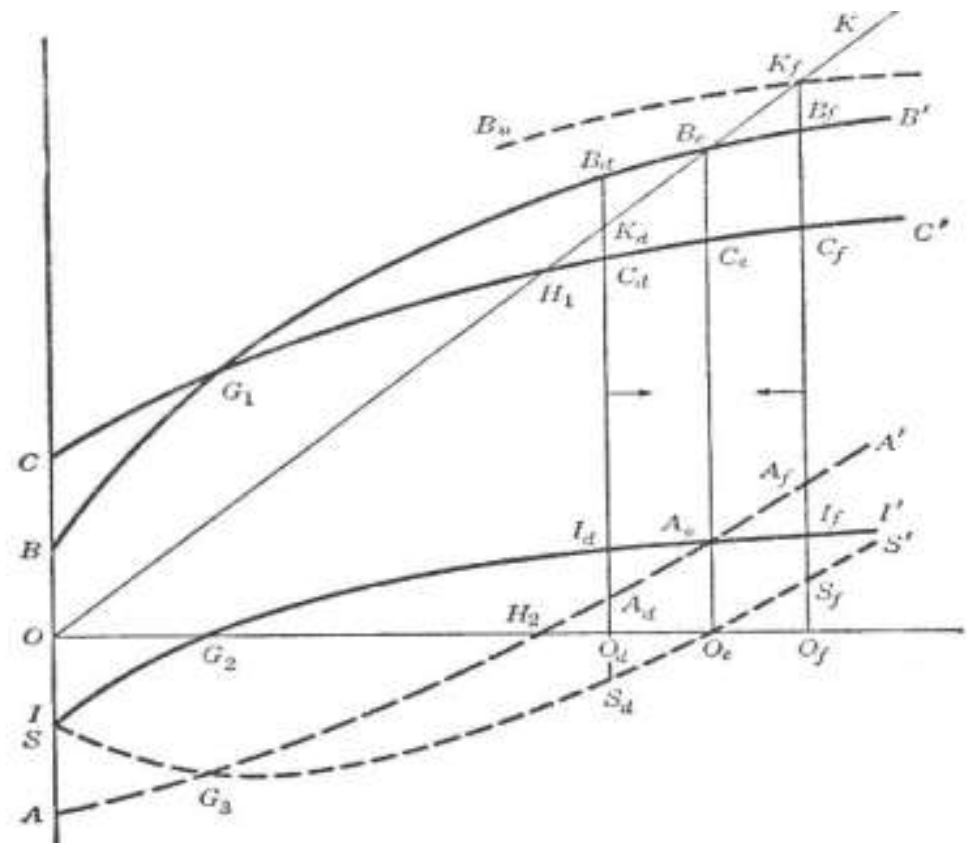

Figure 1. Macroeconomic equilibrium

Production must be reduced in terms of consumption and accumulation (investments). Because the consumption does not decrease as much as the production, the reduction of the production causes a decrease of the accumulation until the surplus is zero. If the inclination towards absorption is high, consumption and investment decrease sharply as production decreases, which reduce the effect of the decline of production on accumulation. Therefore, the decline should go long before the surplus is eliminated. We will assume that at a production of 200 , the desired absorption is 180 , leaving a surplus accumulation of 20 . If the company reduces its production to 180 , it will have an excess accumulation, because the absorption will also be low, for example until 165, however, remaining a surplus of 15 , and production should be further reduced. The phenomenon is sometimes known as a vicious spiral. Attempting to reduce additional unforeseen accumulation by reducing production has the effect of reducing income, which in turn leads to lower consumption. This decrease in consumption partly compensates for the decrease in production, so that production must continue to decrease until the declining production exceeds the decreasing consumption and even the availability to accumulate, i.e. to return to an equilibrium point. Of course, these expectations are theoretical, but the mentioned aspects can appear on macroeconomic aggregates, when there is no demand on the domestic or international market.

\section{- A model with full employment}

The equilibrium of underemployment can only exist if the consumption and investment functions are stable and not affected by the level of unemployment. It is not difficult to extend the basic model by adding another variable, namely unused capacity $U$ and then agreeing that both consumption and investment are themselves related to unused capacity, as well as production reserves. As long as there is an unused capacity $U>0$, then the function of consumption plus investment will increase linearly, that is by an arithmetic progression. When these functions increase and $P$ will increase, and $U$ will decrease to $U=0$, when the growth of $C_{0}, A_{o}$ and $P$ will cease.

Regarding the graphical analysis, this means that, in figure 1 , if there is no unused capacity, the total absorption curve will move up until it reaches a position $\mathrm{B}_{\mathrm{u}} \mathrm{K}_{\mathrm{f}}$, where it intersects the right 45 degrees at the point $\mathrm{C}_{\mathrm{e}}$. 


\section{- Keynesian controversy}

The dispute between the theorists of the Keynesian school and the classical school of employment is at the heart of the problem of measuring what actually exists and which corresponds to the behavioral equations we have presented. The discussion of the behavioral models involved must be subordinated to the operations of the monetary systems and prices. The Keynesian model assumes that there is no natural tendency in the system that tends to increase the level of the absorption curve, since production falls below capacity and under the conditions of full employment, then there must be an active government intervention to raise the level of the curve of absorption to the point where the capacity production will not have surplus accumulations. Under these conditions we can consider this government intervention as itself part of a balance system and suppose that an increase of $U$ over a certain critical level will cause an expansion activity on the part of the government and vice versa. Therefore, $\mathrm{U}=\mathrm{O}_{\mathrm{e}}$ would be a true balance, although the behavioral equations that determine it are based on political behavior and less on strictly economic behavior.

\section{- The classic system: deflation of prices and not of results}

The classical assumption regarding the behavior underlying the equations is that the development of surplus accumulation or overvaluation will produce a downward pressure on prices and not on results. If all markets are competitive and therefore all prices are flexible, it indicates that this assumption is not plausible. Unwanted stockpiles of goods will cause deflation as the owners of these additional stocks are trying to get rid of them by capitalizing on low prices. Similarly, if the labor market were competitive, unemployment would cause downward pressure on wages which would complement and encourage the general fall in prices.

\section{- Some effects of deflation}

The economic consequences of deflation, which is the result of a general decline in prices and wages, are complex. However, it can be expected that two major sets of consequences will affect consumption and investment functions. First, deflation produces a redistribution of income and wealth between different groups and classes of people in society. People who have fixed incomes or who are relatively inflexible in the financial market, earn at the expense of those whose incomes in dollars are flexible. There are earnings of bond holders, debt holders in general, retirees, people living on rent and people with salaries that are established by contract or agreement and are changed only in times of severe pressure. These gains are earned at the expense of business people, farmers, people living on profits in general, people whose incomes depend on prices or flexible wages. Therefore, these changes in the distribution of income can increase the consumption function, because people who are constantly earning achieve low savings. Losers generally have large savings, businessmen and farmers, people in the forefront of life consume much less than they produce. Therefore, deflation stimulates the transition from large to small economies and encourages the consumption of people who earn more. Therefore, it results in an increase in the amount that will be consumed at each income level, that is, an increase in the consumption curve. The effects of income redistribution on the investment curve are more difficult to estimate, but the effects may be unfavorable to investments. Businessmen and farmers are the ones who make the major investment decisions and aim to hold stocks of goods, these being the main factor influencing the level of the investment function.

The profitable producer gets his income by selling more than he buys. If in the interval between buying and selling all prices have fallen, the chance of the sales value exceeding the value of the purchases is even lower. In extreme deflation, profits can even completely disappear and lead to losses. In these circumstances, it is difficult to have concerns about increasing the holdings of goods, because precisely the possession of these goods, which decreases the price, is the cause of the loss. We can expect deflation to have a negative effect, at least in the short term, on the investment function. The net effect of the redistribution of income and wealth achieved by deflation depends on the relative size of the effects on consumption and on investments, which is likely to serve the variant to compensate each other.

If the consumption increase is greater than the decrease of the investments at each level of production, the net effect will be an increase of the total absorption curve and implicitly an increase of the 
production. If the decrease of investments at each level of production exceeds the increase of consumption, the system is in a delicate situation. The result of the accumulation of the surplus will be a decrease of the total absorption curve, an increase of the surplus and a further decrease of the production. The product will decrease in this case until it reaches a level imposed by the need to maintain at least a subsistence level of consumption and the impossibility of divesting more than the rate established by the physical decomposition. According to figure 1 , if the effect of deflation is to decrease investment by more than consumption increases, then instead of the total absorption curve moving up from the BrBf line to the BuKf line under the impact of unused capacity, the curve will move down, thus increasing unused capacity and will continue to move down until the effect becomes favorable on consumption and only outweighs the adverse effect on investments.

\section{- The liquidity effect}

The deflation effect is not the only one that may be relevant to the absorption function. There is also a liquidity effect. If the money supply is constant, decreasing the level of wage prices increases the purchasing power of the existing money supply. People have higher liquidity with a larger proportion of money in their total asset structure, because the monetary value of other assets has decreased. Therefore, this increased liquidity should encourage both consumption and investment. It is reasonable to consider that increased monetary mass at constant prices will encourage consumption and investment, as the increasing monetary mass stimulates a greater inclination towards consumption and investment. A drop in prices with constant money supply should have the same result. Therefore, it can be assumed that the liquidity effect increases the inclination towards consumption and compensates, at least partially, the reduced effect for investments. It increases the likelihood that the existence of unused resources will increase instead of decreasing the total absorption curve and, therefore, ensures a more plausible employment balance. We will find that the difference between the two systems is based on the development of surplus stocks that will lead to reductions in production or prices. If labor and commodity markets are organized, where collective bargaining is the rule and where workers offer strong resistance to reducing wages, the Keynesian model is more plausible. Where all markets are competitive and prices and salaries extremely flexible, the classic model may be closer to reality. In most modern societies, there is a conservative tendency for prices and wages to remain constant and controllable.

\section{- Inflation in the basic model}

The basic model also sheds light on the problem of inflation, although a complete treatment must be postponed until additional solutions are emerging. Inflation is manifested when the equilibrium output of the basic model is greater than the production capacity. Obviously, production cannot extend beyond capacity and, therefore, if there is still an accumulation deficit in the production capacity, and the company still wants to consume and accumulate more than it produces, then the changes must take place in the company that it will seek to escape the accumulation of the deficit in ways other than by expanding production. Suppose the output capacity was $\mathrm{OO}_{\mathrm{d}}$. At this moment the accumulation deficit is $\mathrm{K}_{\mathrm{d}} \mathrm{B}_{\mathrm{d}}$, which indicates that the employers want to accumulate more than they can do and therefore there is a shortage of stocks. In this case, the output adjustments are impossible, unless it is possible, especially in conditions of force majeure, for a company to expand its capacity beyond what was anticipated. If there is an accumulation deficit within which even the limits of extreme capacity have been reached, the result will be inflation or government intervention designed to influence the consumption and accumulation curves.

\section{- Inflation mechanism}

The impact of inflation on consumption and investment functions is the concern at the moment. This impact, as in the case of deflation, is possible through two main mechanisms, through the redistribution of income on the one hand and the effect of liquidity on the other. Both operate in a direction opposite to how they act in deflation. Thus, inflation redistributes income to profit producers and holders of goods and any of the debt holders and persons with relatively fixed monetary incomes. In this case, the winners are probably those with savings and those who lose, who have small savings. The effect of redistribution is likely to be a drop in consumption at every level. The effect on investments will be the other way around, 
that is, high inflation-determining returns encourage investment. Ownership of goods becomes profitable and thus the concern to accumulate will increase. The net effect of the redistribution depends on the size of these changes. If the effect on consumption is large and on investment is small, the net effect will be a decrease in the total absorption curve and, therefore, inflation will decrease the accumulation of the deficit and restore the balance. If, however, the effect on consumption is small and investment is large, inflation stimulates the accumulation deficit and inflationary growth. In such a case, inflation leads to hyperinflation, in which case the rate of price increase approaches a limit set by physical circumstances. This limit, if judged from the experience of hyperinflation, can be about $100 \%$ per week.

\section{- The effect of liquidity on inflation}

Inflation can also have a liquidity effect. If the price increase is faster than the increase of the money supply, then even if the money supply is increasing, the population has less liquidity, because the purchasing power of the money supply decreases. This may influence them, so that they are less willing to consume and invest at each level of income, because they consider that their power to consume and to invest is lower. Therefore, the liquidity effect operates in the sense of decreasing consumption functions and investments and, therefore, has a double effect of restricting the total absorption. It is an effect that helps restore balance. In conclusion, we can see that there is a certain constant rate of inflation at which the total absorption curve is influenced to the point where there is no deficit or surplus in accumulation.

\section{Conclusions}

From the study of this article based on a broad analysis of the situation of a national economy, it was concluded that, based on a basic model that is the best tool to analyze, draw conclusions and intervene with measures to ensure development balanced economy. Also, another conclusion is that the basic model must take into account the effect of inflation and unemployment, which are detrimental to maintaining the balance, but which are properly analyzed, forecasted can be modeled so that the macroeconomic evolution does not go too far. by the state of equilibrium.

The basic model used at the macroeconomic level, is the one from which the adaptation of any model that has to take into account the requirements of this model, but also the realities of the market must begin. This is done by studying the large data series, the parallel series, as well as the graphical representations that give the evolution trend and the effect that the factorial variables can have on the resultant variable, in our case the harmonious evolution of the economy based on strategies based on the parameters estimate based on this basic model.

\section{References}

1.Anghelache, C., Petre, A., Olteanu, C. (2019a), Some concepts and econometric models of macroeconomic performance analysis, Romanian Statistical Review, Supplement, no. 4, pp. 12-20.

2.Anghelache, C., Anghel, M. G., Marinescu, A. I. (2019b), The main indicators of national wealth that have an effect on macroeconomic performance, Romanian Statistical Review, Supplement, no. 3, pp. 14-2.

3.Anghelache, C., Anghel M. G. (2019), Statistică economică generală, ediția a doua, revizuită și adăugită, Editura Economică, Bucureşti, 524 pp.

4. Anghelache, C., Anghel, M. G. (2019c), Modelare economică. Teorie şi studii de caz, ediția a doua, revizuită și adăugită, Editura Economică, Bucureşti, 404 pp.

5.Anghelache, C., Anghelache, G. V., Bârsan, O. (2019), Modelul TRAMO - SEATS utilizat în analiza seriilor dinamice/TRAMO - SEATS model used in the dynamic series analysis, Romanian Statistical Review, Supplement, no. 6, pp. 3-15/16-27.

6. Bollerslev, T. \& Wooldridge, J. M. (1992), Quasi-Maximum Likelihood Estimation and Interference in Dynamic Models with Time-Varying Covariances, Econometric Review 11, 143-72.

7. Ledoit, O. \& Wolf, M. (2003), Improved Estimation of the Covariance Matrix of Stock Returns with an Application to Portofolio Selection, Journal of Empirical Finance, 10.5, 603-21.

8. Ruth, M., Hannan, B. (2012), Dynamic Economic System, second edition, Springer New York Dordrecht Heidelberg London. 
9. Scaillet, O. (2004), Nonparametric Estimation and Sensitivity Analysis of Expected Shortfall, Mathematical Finance, 14, 115-29.

10. Stambaugh, R. F. \& Yuan, Y. (2017) Mispricing Factors, Review of Financial Studies 30, 1270-315. 